How does the Flow of Remittances Affect the Trade Balance of the Middle East and North Africa?

\author{
Mohammad Reza Farzanegan \\ Sherif Maher Hassan
}

CESIFO WORKING PAPER NO. 6172

CATEGORY 1: PUBLIC FinANCE

NOVEMBER 2016

An electronic version of the paper may be downloaded

- from the SSRN website:

- from the RePEc website:

- from the CESifo website:

wWw.SSRN.com

www.RePEc.org

www.CESifo-group.org/wp 


\title{
How does the Flow of Remittances Affect the Trade Balance of the Middle East and North Africa?
}

\begin{abstract}
Middle Eastern and North African (MENA) economies have had the highest degree of dependency on received remittances worldwide over the last three decades. The region has also had the highest non-oil external trade balance deficit among developing countries. We examine the role of remittances in the trade balance of 11 labor-abundant MENA countries. Our panel regression analysis shows that the inflow of remittances has had an increasing effect on trade deficits by triggering import-led consumption expenditures. The results are robust after controlling for other drivers of trade deficit and fixed effects.
\end{abstract}

JEL-Codes: D140, F220, F240.

Keywords: remittances, Middle East and North Africa, trade balance, panel regression.

Mohammad Reza Farzanegan

Philipps-University Marburg

School of Business \& Economics

Deutschhausstrasse 12

Germany-35032 Marburg

farzanegan@uni-marburg.de

\author{
Sherif Maher Hassan* \\ Philipps-University Marburg \\ School of Business \& Economics \\ Deutschhausstrasse 12 \\ Germany - 35032 Marburg \\ sheriff.hassan@staff.uni-marburg.de
}

*corresponding author

Sherif Maher Hassan acknowledges the financial support of Yousef Jameel Academic Program (YJAP) doctoral scholarship. We thank helpful comments of participants at CNMS Research Colloquium, Brown Bag seminar at School of Business and Economics (Marburg), and the 30th Annual Congress of the European Economic Association (2015, Mannheim). 


\section{Introduction}

Personal remittances play an important role in the economies of MENA countries. While in absolute terms, they are ranked fourth after Europe and Central Asia, East Asia and the Pacific, and Latin America and Caribbean, in relative terms, they have been ranked first worldwide (1.77\% of GDP) over the last three decades (World Bank, 2016).

Inflows of remittances to the region are driven by inflows to Labor Abundant (LA) countries, with remittances comprising, on average, 6.74\% of LA countries’ GDP between 1980 and $2013^{1}$ (ibid). However, during the same period, MENA has been accumulating a deficit in its non-oil external trade balance. Figure 1 shows the difference between non-oil exports and non-oil imports of MENA against other developing regions. MENA has a deficit of $19.4 \%$ of GDP, which is the highest among the developing regions.

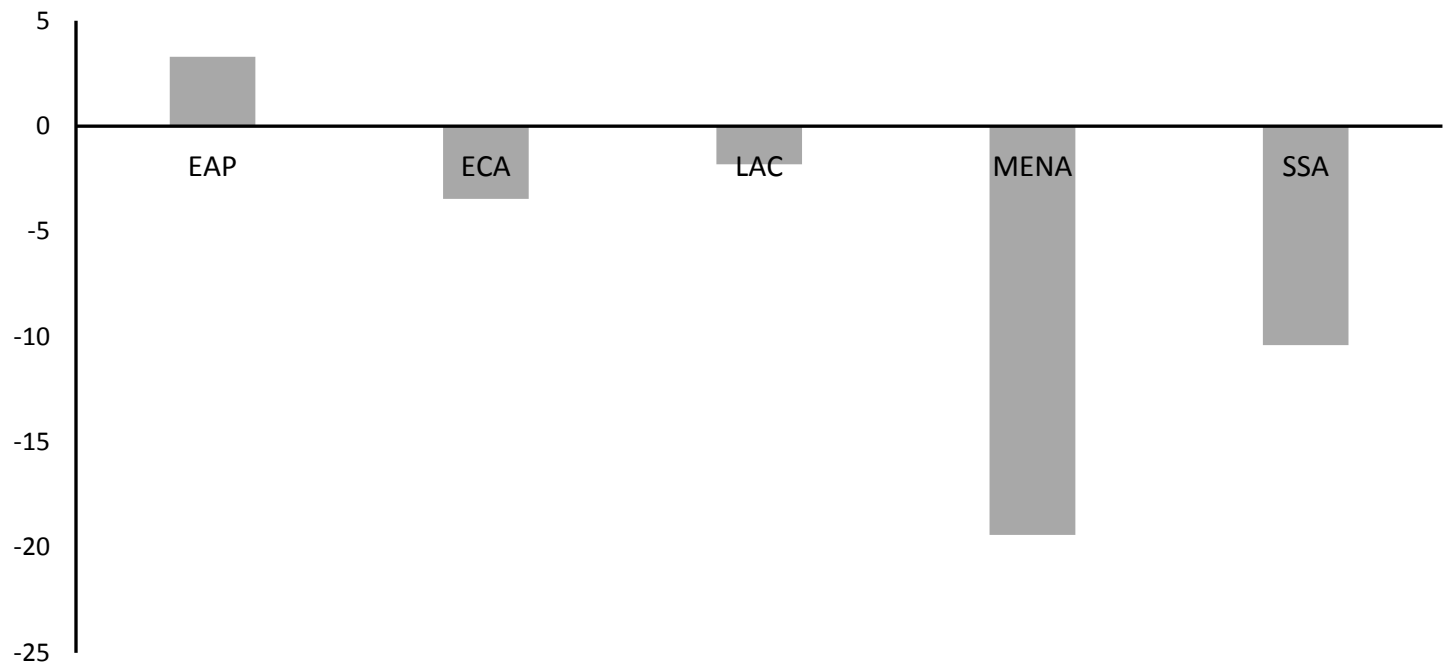

Figure 1. Non-oil external trade balance (\% GDP). Selected world regions (1980-2013)

\footnotetext{
${ }^{1}$ The World Bank (2007) classifies MENA countries according to labor and resource abundance based on the ratio of the native population to the foreign and expatriate population and the extent of dependence on natural resources. They form three groups: (1) Resource Poor Labor Abundant (RPLA) - Egypt, Jordan, Lebanon, Morocco, and Tunisia; (2) Resource Rich Labor Abundant (RRLA) - Algeria, Iran, Iraq, Libya, Syria, and Yemen; and (3) Resource Rich Labor Importing (RRLI): Bahrain, Kuwait, Oman, Qatar, Saudi Arabia, and the United Arab Emirates. This last group is referred to as Gulf Cooperation Council (GCC) countries. Because of data limitations for GCC countries for remittances received, these countries are classified as labor-importing economies and thus are excluded from our analysis.
} 
Notes: Non-oil external trade balance is calculated as (exports of goods and services - fuel exports) minus (imports of goods and services - fuel imports). EAP (East Asia and Pacific), ECA (Europe and Central Asia), Latin America and the Caribbean (LAC), Middle East and North Africa (MENA), and SSA (Sub-Sahara Africa).

Source: World Bank, (2016).

World Bank (2003) estimations show that by reducing the merchandise export gap by half, MENA could generate an additional 4 million jobs over a period of five years and increase women's participation in the labor force at the same time. Our research investigates the impact of remittance inflows on the non-oil external trade balance of LA-MENA countries.

One possible reason for the trade deficit is the existence of a current account deficit due to the 'twin deficit hypothesis' (Congressional Budget Office [CBO], 2000). A deficit may reflect a shortfall in domestic national savings relative to investment (Elwel, 2007). However, LA-MENA countries have been experiencing an increasing general trend in current account balances in the last three decades (World Economic Outlook, 2015). A trade deficit may also point to a highly productive and growing economy; some manufactured imports can be used as intermediates for the production of future exports. Nevertheless, our sample of countries and the MENA region in general has the lowest global share of manufactured exports (World Bank, 2016). Consequently, no alternative exists to finance the sustained trade deficit that is expect to accumulate external debts (Shakur, 2012), which is observed from the mounting regional multilateral debt from \$5.4 billion to \$44.6 billion during the period 1980-2013 (World Bank, 2016).

A weak industrial sector, which fails to provide domestic substitutes for imports of manufactured products, is the main driver of the trade deficit in the MENA region (El Wassal, 2012; Hadad, 2001). The region has a weak export structure that is concentrated in fuel and primary commodities, while imports are driven by food and manufactured goods (El Wassal, 2012; Hadad, 2001). The falling prices of primary commodities, which represent the largest component of our sample countries' exports relative to those of imported manufactured products, partially explain the prolonged trade deficit (Thirlwall, 1999; El Wassal, 2012; Hadad, 2001).

Running a trade deficit for a sustained period of time increases country's debt levels, and with a low sovereign credit rating, this causes sources of future borrowing to dry up (Shakur, 2012). Dependence on imported consumption and intermediate goods create additional pressures of imported inflation that adds to the existing high inflation rate figures in MENA (Mim and Ben 
Ali, 2011). It also results in economic instability and the stagnation of domestic economy production capabilities (Chaudhary and Qaisrani, 2002).

The import-triggering effects of remittances (the boomerang effect) have been observed in Latin America and Sub-Saharan Africa (Organisation for Economic Co-operation and Development [OECD], 2006), but studies on the MENA region are limited and have mixed findings. For example, Kandil and Mirzaie (2011) used a time series analysis and found that export growth increases significantly with remittance inflows in only two (Jordan and Tunisia) out of a sample of four LA countries. El-Sakka and McNabb (1999) analyzed the effect of interest and inflation rates on the inflows of remittances to Egypt and found that imports financed through remittances have high-income elasticity. This suggests either that these imports are consumer durables and luxury goods or that they are undertaken by higher income groups. Conversely, Bouhga-Hagbe (2004) found in the case of Morocco that remittances almost covered the trade deficit and explained the observed surpluses of the external current account.

The contribution of this research is three-fold. First, this is the first panel study with a full sample of 11 LA-MENA countries that investigates the trade balance effects of remittances between 1980 and 2013. Second, our research follows studies by Ramirez and Sharma (2008) and Giuliano and Ruiz-Arranz (2006) on Latin America, which examined how domestic production affects the trade balance effects of remittances. Third, we use a reduced form equation for the trade balance based on imperfect substitute models in Goldstein and Khan (1985), Rose and Yellen (1989), and Stučka (2004) to model and provide quantitative evidence of our introduced remittance-trade balance savings channel.

Our panel regression fixed effects (FE) and two-stage least squares (2SLS) for 11 LA-MENA countries from 1980 to 2013 provide robust evidence for the import triggering effects of remittances in LA countries. We have found evidence for the moderating role of domestic production capacity in reducing the negative effect of remittances on the non-oil trade deficit in 2SLS regressions. This means that LA countries in MENA that have increased domestic production and investment may also benefit from received remittances as a new source of funding and increases in the export sector. 
In section 2, we discuss the literature on the trade balance effects of remittances. Section 3 outlines the theoretical model, and section 4 presents the empirical methodology, data and estimation result. Section 5 concludes the paper.

\section{Literature Review}

Trade expansion in the form of increasing manufacturing exports has been an important source of growth in developing countries (De Silva and Jáuregui, 2004). The MENA region is characterized by a weak industrial base, which could provide a partial explanation for weak export performance. Prices of primary exports relative to imported manufactured products have also been deteriorating for at least a century, which explains the prolonged trade deficit (Thirlwall, 1999; El Wassal, 2012).

One method of correcting a trade deficit is to trigger private savings and channel it towards domestic investment to widen the pool of domestically manufactured products. Remittances can be a catalyst for private savings and per capita income (Koska et al. 2013; Anwar and Cooray, 2015; Drinkwater et al., 2003). The literature identifies two channels through which remittances affect the receiving countries' trade balance: the exchange rate and the savings channels. Through the exchange rate channel, remittance inflows may be so significant in volume as to result in the appreciation of the real exchange rate of the receiving economy. This results in a reduction of foreign trade competitiveness and adversely affects the balance of trade as well as the economic development of the receiving economy (Okodua and Olayiwola, 2013). This could also generate resource allocation from the tradable to the non-tradable sector, known as the Dutch disease (Amuedo-Dorantes and Pozo, 2004; Jahjah et al., 2003).

This study is concerned with the saving channel, in which there are three scenarios. The first occurs when a substantial portion of the remittances is saved by the migrants' families in financial institutions. These deposits promote the ability of these institutions to finance domestic production and will either enhance the provision of domestic substitutes of manufactured imports or stimulate exports. Both will help alleviating an existing trade deficit (Kandil and Mirzaie, 2011; Bouhga-Hagbe, 2004; World Bank, 2006). 
In the second scenario, the domestic output matches the majority of remittance-induced consumption expenditures. Similar to the first scenario, remittances will either boost exports or stimulate domestic production competencies to provide substitutes for imports. Both will generate favorable trade balance effects (Gopalan and Rajan, 2010; Taylor, 1996).

The third scenario arises if domestic capacity constraints are binding and the majority of additional demand that is induced by remittances cannot be neutralized by domestic output. The increase in consumption will be inflationary and will stimulate a further increase in imports (OECD, 2006; De Silva and Juregui, 2004).

The following qualitative and quantitative evidence support the likely occurrence of the third scenario, implying that the largest fraction of remittances is consumed and that the majority of the provoked expenditures are channeled towards imported items. Household budget surveys, which represent the best source of information about how remittances are spent, are limited for the MENA region. Adams (1991) conducted surveys of 1,000 households in rural Egypt and showed that more than $70 \%$ of remittances were used to purchase agricultural or developing land, and approximately $12 \%$ was dedicated to consumption expenditure. International Organization for Migration [IOM] (2012) showed that remittances to Egypt were primarily channeled towards essential expenses and consumption, and approximately $20 \%$ was invested in real estate and other forms of productive investments.

European Investment Bank [EIB] (2006) undertook field studies on the remittance use of alternative budget items in selected LA-MENA countries. Table A1 in Appendix A shows that daily expenses absorb most of the income from remittances and that little is devoted to investment. Schramm (2009) and Mim and Ben Ali (2012) argued that basic consumption items (food, heat, and clothing) absorb most remittances in the MENA region. Extra evidence for the consumption use of remittances is highlighted by Figure 2, which shows steady household private savings over the investigated period despite the increasing inflows of remittances. Moreover, the plotted panel regression line in Figure A1 shows a steep positive relationship between remittances and household consumption expenditures. 


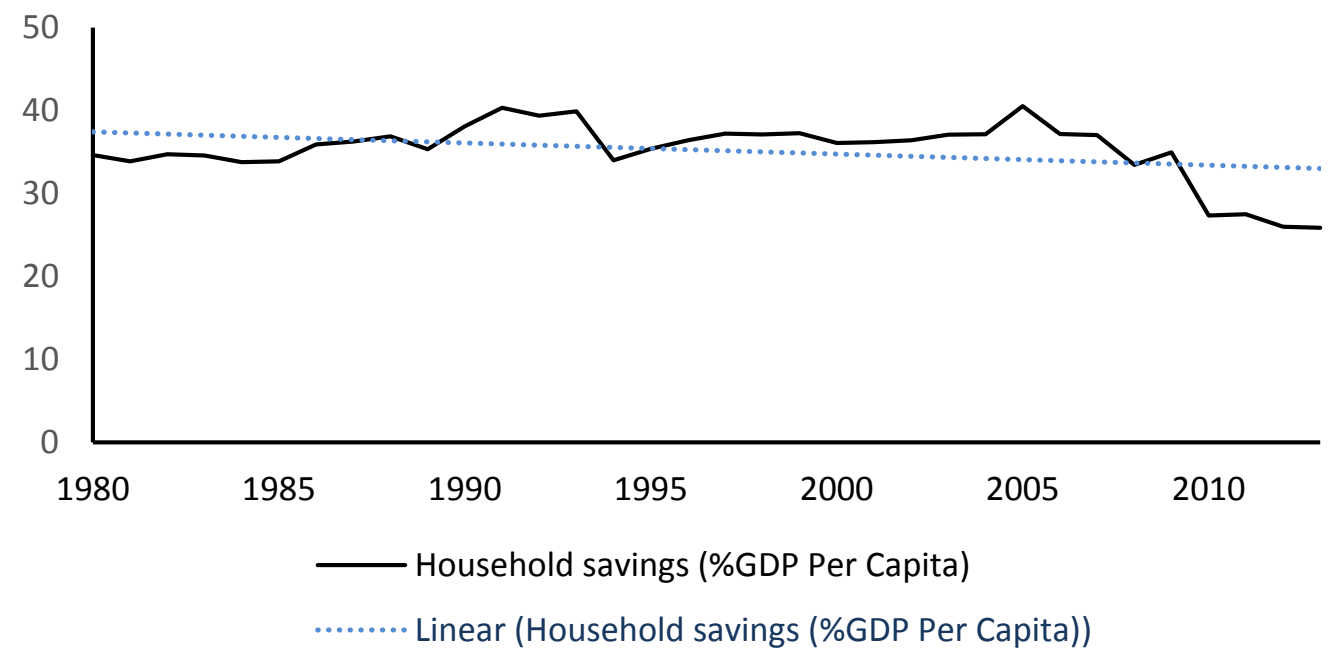

Figure 2: Household private savings (\% GDP per capita). LA countries (1980-2013)

Notes: Household private savings is calculated as the difference between GDP per capita and household final consumption expenditures per capita. LA (Labor Abundant MENA countries)

Source: World Bank, (2016)

Domestic production capabilities are limited in our sample of countries due to weak institutions (Page and Van Gelder, 2001), the poor link between the education system and manufacturing sector (Makdisi et al., 2007), low growth rates (Bhattacharya and Hodler, 2010), the lack of infrastructure (Nabli, 2007), a weak private sector (World Bank, 2009), and the adverse economic impact from the 'Arab Spring' since 2010. This leaves no room for remittance-induced consumption expenditure except to trigger imports of goods and services. The negative correlation between household final consumption expenditures in our sample of countries and the external trade balance is also highlighted by the panel regression for our cloud of data in Figure A2.

When remittances induce an increase of imports and trade balance deficits in the receiving country, this is known as the 'boomerang effect'. However, the propensity to import can also increase as a consequence of the general development of the economy (OECD, 2006). In southern Europe between 1960 and 1981, remittance-induced imports accounted for 1\% in Spain and Italy and up to $4.9 \%$ in Greece and 6.2\% in Portugal (Glytsos, 1993; Straubhaar, 1991). Other studies have supported the boomerang effects of remittances to Sub-Saharan Africa (Okodua and Olayiwola, 2013), Nepal (Bhatta, 2013), and Latin America (Loser et al., 2006). 
The literature on the MENA region is limited and has shown mixed findings. Kandil and Mirzaie (2011) found that export growth increased significantly with remittance inflows in only two (Jordan and Tunisia) of a sample of four LA countries. El-Sakka and McNabb (1999) analyzed how interest and inflation rates affect inflows of remittances to Egypt and found that imports financed through remittances have a high-income elasticity, which suggests either that these imports are consumer durables and luxury goods or that they are undertaken by higher income groups. Conversely, Bouhga-Hagbe (2004) found that in Morocco, remittance receipts almost covered the trade deficit and explained the observed surpluses of the external current account.

\section{Theoretical model}

We develop a trade balance reduced form equation following the imperfect substitute's models (Goldstein and Khan, 1985; Rose and Yellen, 1989; Stučka, 2004). Our model’s underlying assumptions are, first, that domestic and foreign goods are not perfect substitutes; otherwise, we would notice either that domestic or foreign goods cover the whole market or that a country could only be an importer or an exporter of goods, but not both. Since these predictions are counterfactual to the data (Stučka, 2004), we accept the imperfect substitute hypothesis.

The second assumption is that remittances are treated as an exogenous source of permanent income. Since qualitative evidence is equivocal as to whether households consider remittances permanent or transitory and given that the studies implying that the majority of remittances are absorbed by consumption expenditures, this implies that remittances are part of the permanent income according to Friedman's 'permanent income hypothesis'. The third assumption is that we are operating in a barrier-free world with no tariffs in which foreign goods are sold in domestic markets at their initial prices after adjusting for exchange rates.

We build on Stučka (2004) and add two variables: remittances (R) and capital stock accumulation (K). The imports' demand function is:

$$
M=f_{1}\left(Y, \pi, R, \pi_{m}, K\right), \frac{\partial M}{\partial Y}>0, \frac{\partial M}{\partial \pi}>0, \frac{\partial M}{\partial R}>0, \frac{\partial M}{\partial \pi_{m}}<0, \frac{\partial M}{\partial K}>0
$$


where $\mathrm{Y}$ denotes domestic income, $\pi$ is the domestic headline inflation rate, $\pi_{m}$ is the domestic currency price paid by domestic importers, $\mathrm{K}$ is the capital stock, and $\mathrm{R}$ is the remittances.

We treat remittances as an exogenous variable, wherein its impact on imports is not direct but depends on the share of remittances allocated by households to imported products. According to the savings channel theory, we expect remittances to finance household consumption expenditures, in line with previous studies (EIB, 2006; Schramm, 2009; Mim and Ben Ali, 2012). Given the weak industrial sectors, which are unable to provide domestic substitutes for manufactured imports, and that imports make up a relatively high proportion of household consumption (Glytsos, 1993), the partial derivative of remittances to imports is positive.

The capital stock accumulation (K) reflects investments in tangible means of production, human capital, social capital, etc. A productive and growing economy tends to use intermediate inputs that have no domestic substitutes; hence, we expect to see a positive impact of $\mathrm{K}$ on $\mathrm{M}$ in the preliminary phases of development. Equation 2 expresses the rest of the world demand for imports $\left(\mathrm{M}^{*}\right)$ :

$$
M^{*}=f_{2}\left(Y^{*}, \pi^{*}, \pi_{m}^{*}\right), \frac{\partial X}{\partial Y *}>0, \frac{\partial X}{\partial \pi^{*}}>0, \frac{\partial X}{\partial \pi_{m}^{*}}<0
$$

where $Y^{*}$ is foreign income, $\pi^{*}$ is the foreign headline inflation rate, and $\pi_{m}^{*}$ is the foreign currency price paid by domestic importers. We then divide the right-hand side variables by their corresponding aggregate price levels to express both functions in real terms:

$$
\begin{aligned}
& M=f_{1}\left(Y_{r}, R_{r}, P, K_{r}\right) \text {, where the relative price of imports to domestic products is } \\
& \begin{array}{l}
(P)=\pi_{m} / \pi \quad \frac{\partial M}{\partial Y_{r}}>0, \frac{\partial M}{\partial P}<0, \frac{\partial M}{\partial R_{r}}>0, \frac{\partial M}{\partial K}>0 \\
M^{*}=f_{2}\left(Y_{r}^{*}, P^{*}\right) \text {, where the relative foreign price of imports is } \\
\left(P^{*}\right)=\pi_{m}^{*} / \pi^{*} \quad \frac{\partial X}{\partial Y^{*}}>0, \frac{\partial X}{\partial P^{*}}<0
\end{array}
\end{aligned}
$$

The relative domestic price of imports is equal to the foreign currency price of foreign exports after adjusting exchange rates, so we can rewrite $P$ as follows: 


$$
P=\pi_{m} / \pi=\frac{e \pi_{X}^{*}}{\pi}=\frac{e \pi^{*}}{\pi} \frac{\pi_{X}^{*}}{\pi^{*}}=Z \frac{\pi_{X}^{*}}{\pi^{*}}=Z \pi_{X}^{*}
$$

$\mathrm{Z}$ is the real exchange rate, which is written in such a way that its increase implies a depreciation of domestic currency. $\pi_{X}^{*}$ is the real foreign price of exports.

When modelling the domestic supply of exports, $\mathrm{X}$, we also add $\mathrm{R}$ and $\mathrm{K}$ to our equation. $\mathrm{R}$ is based upon the illustrated savings channel and entails positive externalities on exports in only two scenarios: a) when significant portions of remittances are saved in financial institutions that leverage their financial ability and allow wider participation in promoting export competitiveness and b) when remittances are consumed but increase demands on domestic production, thus stimulating production and exports. The latter scenario is unlikely because consumption expenditures absorb the largest portion of remittances. Therefore, remittances have a negative partial coefficient with domestic exports.

The domestic supply of exports $\mathrm{X}$ and the foreign supply of exports to the rest of the world $X^{*}$ are expressed by the following equations:

$$
\begin{aligned}
& X=f_{1}\left(\pi_{X}, \pi, K, R\right), \frac{\partial X}{\partial \pi_{x}}>0, \frac{\partial X}{\partial \pi}<0, \frac{\partial X}{\partial K}>0, \frac{\partial X}{\partial R}<0 \\
& X^{*}=f_{2}\left(\pi_{X}^{*}, \pi^{*}\right), \frac{\partial X^{*}}{\partial \pi_{x}^{*}}>0, \frac{\partial X^{*}}{\partial \pi^{*}}<0
\end{aligned}
$$

where $\pi_{x}$ is the domestic currency price received by exporters. In the equilibrium, the following conditions are required: $M=X^{*} e$ and $M^{*}=X$. Finally, the domestic trade balance (T) is defined as:

$$
T=\pi_{X} M^{*}-Z \pi_{X}^{*} M
$$

We then solve for domestic exports and imports and obtain the following partial reduced form of the trade balance $(\mathrm{T})$ :

$$
T=\left\{Y^{*}, Z, Y, K, R\right\}, \frac{\partial T B}{\partial Y^{*}}>0, \frac{\partial T B}{\partial Y}<0, \frac{\partial T B}{\partial K}<0, \frac{\partial T B}{\partial R}<0, \frac{\partial T B}{\partial Q}>0
$$


$\mathrm{T}$ is positively correlated with foreign income and real exchange rate, while domestic income, capital stock accumulation, and remittances exercise adverse effects on $\mathrm{T}$.

\section{Data and empirical specification}

Our main prediction is that remittance flows have a dampening impact on the trade balance of LA-MENA countries. This negative trade balance effect is derived by the triggered remittanceinduced consumption expenditures that are not matched with domestic production. We test this hypothesized negative correlation, which is conditioned to strong and dynamic domestic production (OECD, 2006; Brown et al. 2014).

This study is limited to 11 LA-MENA countries. We use panel data for the period 1980 to 2013. Our dependent variable is trade balance ( $t b)$, measured as the export of goods and services minus the import of goods. The main independent variables are (remit) remittance inflows, (inv) gross fixed capital formation as an indicator for additions to capital stock, and the interaction term (remit*inv) to test the effect of domestic investment on the trade balance effects of remittances. The variables are reported as a share of GDP.

We begin with a straightforward specification of our dependent variable $(t b)$ in a linear function of our main independent variables against a set of control variables $(X)$. The subscripts $i$ denote the country (11 countries), $t$ denotes time (1980-2013), $\varepsilon_{\mathrm{i}}$ are the observation-specific errors, and $v_{\mathrm{i}}$ are unobserved individual-specific effects.

$t b_{i, t}=$ cons. $+\beta_{1 .}$ remit $_{i, t}+\beta_{2 .} \cdot$ inv $_{i, t}+\beta_{3} \cdot(\text { remit } * i n v)_{i, t}+\sum X_{i, t}+\mu_{i}+\varepsilon_{i, t}$

To reduce the omitted variable bias, we control for other determinants of trade balance, including annual growth of GDP per capita as a proxy for domestic income (income), a weighted average of real GDP growth for the five main trade partners of each country as a measure of foreign income (foreign income), a real effective exchange rate of local currency vis-à-vis the weighted average of foreign currencies (exchange), and the Polity index (polity) to control for the quality of institutions (Marshal et al. 2011). We also use domestic credit to the private sector (dcr) as a proxy for the degree of development of the financial sector to capture its effects on both the countries' export competitiveness and the capacity of the savings channel (Giuliano and Ruiz- 
Arranz, 2006; Ramirez and Sharma, 2008). In addition, we include natural resource rents (rents) to account for the impact of natural resource exploitation, which constitutes a large share of resource-rich countries' exports. The secondary school enrollment rate (scho) is used as a proxy for human capital and the role of education (WTO, 2013). We take into consideration both the impact of foreign investments (fdi) and development assistance (aid) that can encourage governments to improve the quality of infrastructure and adopt FDI-led export growth strategies with the twin objectives of capturing the benefits of both FDI inflow and export growth (Pfaffermayr, 1996). In addition, we include the inflation rate (inf) as a proxy for macroeconomic instability (Barro and Sala-i-Martin, 2004).

The real effective exchange rate is sourced from Bruegel's database ${ }^{2}$. Information about the main trade partners is obtained from the official statistical organization of each country. The remaining data are from the World Bank (2016). The descriptive statistics and definitions of variables are presented in Tables A2 and A3. We use White's cross-sectional standard errors that are robust to heteroscedasticity and serial correlation in all specifications.

We also control for time-invariant country characteristics such as geography, climate and cultural norms and other time-invariant determinants of the external trade balance. Using fixed effects can reduce the endogeneity problem due to the omitted variables bias of country-specific factors. One concern is the reverse feedback from the trade deficit on our key independent variables, which is partly due to measuring remittances and investment as a share of GDP. The trade deficit may shape GDP and thus serve as a denominator of our key independent variables. One strategy for reducing the problem of reverse feedback is to use the lag of the right-hand side variables (RHS) in our fixed effects regressions. The past development of remittances and investment and other control variables can affect the trade deficit at the current time but not vice versa (for a similar approach, see Bjorvatn and Farzanegan, 2015; Bjorvatn et al., 2012; Bhattacharyya and Hodler, 2010; and Farzanegan, 2014).

\footnotetext{
${ }^{2}$ Bruegel provides a large database for real effective exchange rates. Retrieved from http://bruegel.org/2012/03/realeffective-exchange-rates-for-178-countries-a-new-database/
} 
In another strategy and following Biswas et al. (2012), Imai et al. (2014) and Catrinescu et al. (2009), we estimate the specification with two stage least squares (2SLS) using two-year lags of the main independent variables remit, inv and the interaction term remit*inv as instruments. Verbeek (2004, p. 345) suggests, “In many cases, panel data will provide 'internal’ instruments for regressors that are subject to measurement error. That is, transformations of the original variables can often be argued to be uncorrelated with the model's error term and correlated with the explanatory variables themselves, and no external instruments are needed".

The lags of RHS variables should be correlated with the endogenous variables and are orthogonal to the error term. It is important to test for their relevance and validity conditions. For this purpose, we carry out three tests: (1) the Kleibergen-Paap rk LM test, (2) the KleibergenPaap rk Wald F test, and (3) Hansen's J test. The Kleibergen-Paap rk LM test is used to test for the relevancy of the variables (i.e., correlated with the endogenous variables), where a rejection of this test shows that the instruments do not adequately identify the model. The second test, the Kleibergen-Paap rk Wald F test, examines whether the instruments are only weakly correlated with the selected instrumented variables. This statistic is compared to the critical values (based on bias and size) from Stock and Yogo (2005). The last test is related to the over identification test and is conducted using Hansen's J test. The null hypothesis implies that the instruments are valid. Failure to reject the null hypothesis in this case shows that the instruments are correctly excluded from the equation and are orthogonal to the error term (Baum et al., 2007). The diagnostic test results in Table 2 imply that the employed set of instruments meets both the relevancy and validity conditions ${ }^{3}$.

\footnotetext{
${ }^{3}$ Other instruments for remittances that are commonly used in the literature are the wage gap or unemployment rate differences between the migrants' host and destination countries (Imai et al. 2014; Amuedo-Dorantes and Pozo, 2011 and others). However, the nature of our analysis that captures the aggregated remittance inflows from emigrants around the globe hinders us from using such instruments. Similarly, we are unable to use other instruments such as the cost of money transfers, the education level of the labor force, and the stock of international migrants because of the data scarcity of these variables for our sample of countries.
} 


\section{4-1. Panel fixed effects OLS results}

We empirically test our hypothesis that remittances trigger imports of goods and services that feed into the prolonged trade deficit. Our estimations start by examining remittance inflows (remit) and trade balance (tb), both measured as a share of GDP. Table 1 reports the panel fixed effects regression of Eq. (10). We use a one-year lag for all independent variables to reduce the reverse feedback effect from the dependent variable.

The baseline results are reported in Model 1.1. The trade balance effect of remittances is negative and statistically significant at the 5\% level, meaning a one-unit increase in remit reduces $t b$ (in other words, increases imports at the expense of exports) by 0.433 . This result is robust in Model 1.2, where we add an extended set of control variables.

In Models 1.4, 1.5 and 1.6, we test the sensitivity of our results to the change of the dependent variable. We use (nonoiltrade) as proxy for oil free merchandise trade movements. This variable is calculated as (merchandise exports-oil exports) minus (merchandise imports-oil imports) as a share of GDP. The negative impact of remit remains unchanged. In Model 1.6, the one-unit increase in remit reduces nonoiltrade by 0.767 at the $5 \%$ level while controlling for a full set of control variables

The interaction remit*inv that aims to test the impact of domestic production on the trade balance effects of remittances is not significant in any of the models. This result is explained by the fact that most remittances are absorbed by consumption expenditures that are import driven, and those that were saved are either insignificant in terms of economic activity or were invested in small-scale, non-tradable investments that have nearly no impact on the country's trade balance. This, in turn, hinders the ability for domestic production to exert any clear impact on the trade balance effect of remittances (Ramirez and Sharma, 2008).

As predicted by our theoretical model, inv exercises a negative impact on both dependent variables across all models. Reasons for this countercyclical impact are, first, that domestic investments in general have a significant non-tradable component that alleviates their impact on the country's trade balance (Burstein et al., 2004). Second, domestic investments in LA countries 
are not diversified; they are heavily concentrated in the service and construction sectors, while more than half of their exports are concentrated in three commodities, most of which are primary products: agriculture, crude materials or minerals. In addition, domestic production activities depend on imports of intermediate input mainly because of the lack of domestic capital goods (Hadad, 2001; OECD, 2006) ${ }^{4}$.

The impact of income and foreign income are insignificant. An appreciation in the real exchange rate has a weak negative impact on $t b$, but the result is not robust in nonoiltrade models. This weak and vague magnitude is explained by the fact that the exchange rate requires deeper lags to influence the trade balance due to what is known as the J-curve phenomenon (Bahmani-Oskooee and Ratha, 2004)

\section{4-2. Panel fixed effects 2SLS results}

Table 2 reports the 2SLS estimations of Eq. (10). We use two-year lags of remit, inv and the interaction term remit*inv as instruments. The diagnostic tests of the instrument's validity and relevance conditions are presented. We use trade balance and non-oil trade balance as a share of GDP interchangeably as dependent variables. The complete set of control variables (one year lagged) is included in the models and is treated as pre-determined.

Our theoretical prediction and the former quantitative findings of the import-triggering effects of remittances are supported by our 2SLS estimations. The negative effect of remittances on both trade and non-oil trade balances is robust and slightly higher than our previous results. In Model 2.1, the size of the negative-estimated trade balance effect of remittances is 0.964 at the $5 \%$ level. In Model 2.3, the one-unit increase in remit reduces nonoiltrade by 1.338 at the 5\% level.

We examine the robustness of our results by using per capita remittances in Models 2.2 and 2.4. This strategy tends to reduce the reverse feedback from the dependent variable because there is no direct correlation between the trade balance and population. The per capita estimate of remittances is used in other studies such as Adams and Page (2005) and OECD (2006). Our main results remain robust regardless of which proxy is used.

\footnotetext{
${ }^{4}$ For a better understanding of trade performance, openness and diversity in MENA, see Hadad (2001) and OECD (2007).
} 
The interaction between the remittance per capita and investment carry the hypothesized positive sign, implying that a strong domestic production reduces the negative trade balance effect of remittances. However, this result is not robust when using remittances as a share of GDP or using the panel OLS fixed effects regressions. In all 2SLS estimations, the Cragg Donald F statistics are higher than the Stock-Yogo weak id critical values, implying rejection of the null hypothesis of weak instruments. The Hansen $\mathrm{J}$ statistic fails to reject the null hypothesis of the over-identifying restrictions, suggesting that the instruments are valid. The under-identification test is another test for satisfying the relevancy condition, and rejection of its null hypothesis implies that the model is identified.

\section{Conclusion and policy recommendations}

This research investigated the trade balance effect of the incrementing flows of remittances to LA-MENA countries. The weak industrial base, low share of manufactured exports, and high dependence on finished and intermediate imported goods all indicate the inability of local economies to provide domestic substitutes for imports of finished and manufactured products.

Remittances can spur the accumulation of private savings, and with a channeling towards domestic investments, the economy can widen the pool of domestically manufactured products. This is known as the savings channel. However, the data provided countercyclical evidence for this hypothesis because household private savings did not increase during the investigated period, which suggests that these remittances have induced consumption expenditures rather than savings. Given the inability of domestic economies to match remittance-induced consumption expenditures, this adds additional pressure to LA-MENA countries' trade balance by triggering consumption imports. As a result, increasing remittances in our sample of LA countries in the MENA region is leading to higher trade deficits. The critical question is as follows: To what extent are increasing trade deficits in the long run sustainable and manageable by LA-MENA countries, which also lack access to natural resource rents? These countries will need to finance the increasing imports burden that are fueled partly by increasing remittances and their local spending by borrowing from international markets. Bearing higher debt burdens while their export sector is underdeveloped will increase the risk of economic instability and the likelihood of an economic and political crisis. 
To investigate the effect of remittances on trade balance, we use panel OLS and 2SLS fixed effect regressions for a sample of 11 LA-MENA countries during 1980-2013. Our results support the theoretical prediction of the import-inducing effects of remittances. We also find evidence for the moderating role of domestic production and investment capacity in the final effects of remittances on trade, especially non-oil trade balance. Countries that have managed to increase the domestic investment capacity may be able to reduce the negative trade balance effects of remittances.

To facilitate the investment use of remittances and to promote their favorable impact on the receiving country's trade balance, LA-MENA countries should focus on promoting financial services that target expatriates, such as savings incentives, interest rate premiums on emigrants' deposits, and remittance back bonds to allocate larger fractions of remittances to savings instead of consumption. Additionally, cooperation between diaspora groups, banks, and international financial institutions needs to be instigated to develop cooperative pooling schemes that facilitate investment from remittances and direct them towards industrial and manufacturing investments. This would boost the weak industrial base and help reduce the merchandise trade deficit. 
Table 1: Panel fixed effects regressions

\begin{tabular}{|c|c|c|c|c|c|c|}
\hline & $(1.1)$ & $(1.2)$ & $(1.3)$ & $(1.4)$ & $(1.5)$ & $(1.6)$ \\
\hline & $t b$ & $t b$ & $T b$ & nonoiltrade & nonoiltrade & nonoiltrade \\
\hline remit & $\begin{array}{l}-0.433^{* * *} \\
(-3.44)\end{array}$ & $\begin{array}{l}-0.452^{* *} \\
(-3.14)\end{array}$ & $\begin{array}{l}-0.431 \\
(-1.82)\end{array}$ & $\begin{array}{l}-0.517 * * \\
(-2.44)\end{array}$ & $\begin{array}{l}-0.351^{*} \\
(-2.08)\end{array}$ & $\begin{array}{l}-0.767 * * \\
(-2.92)\end{array}$ \\
\hline inv & $\begin{array}{l}-0.414^{*} \\
(-2.19)\end{array}$ & $\begin{array}{l}-0.362 * * * \\
(-5.72)\end{array}$ & $\begin{array}{l}-0.356 * * * \\
(-4.58)\end{array}$ & $\begin{array}{l}-0.764 * * * \\
(-3.83)\end{array}$ & $\begin{array}{l}-0.497 * * \\
(-2.85)\end{array}$ & $\begin{array}{l}-0.642^{* *} \\
(-3.16)\end{array}$ \\
\hline income & $\begin{array}{l}-0.00986 \\
(-0.05)\end{array}$ & $\begin{array}{l}-0.210 \\
(-1.57)\end{array}$ & $\begin{array}{l}-0.210 \\
(-1.56)\end{array}$ & $\begin{array}{l}-0.210^{* *} \\
(-2.25)\end{array}$ & $\begin{array}{l}-0.0698 \\
(-1.03)\end{array}$ & $\begin{array}{l}-0.0862 \\
(-1.27)\end{array}$ \\
\hline foreign income & $\begin{array}{l}0.0712 \\
(0.40)\end{array}$ & $\begin{array}{l}-0.108 \\
(-0.89)\end{array}$ & $\begin{array}{l}-0.107 \\
(-0.88)\end{array}$ & $\begin{array}{l}-0.0766 \\
(-0.39)\end{array}$ & $\begin{array}{l}-0.195 \\
(-1.20)\end{array}$ & $\begin{array}{l}-0.201 \\
(-1.35)\end{array}$ \\
\hline exchange & $\begin{array}{l}0.0198 * * * \\
(-5.33)\end{array}$ & $\begin{array}{l}-0.00691^{* *} \\
(-2.69)\end{array}$ & $\begin{array}{l}-0.00697^{* *} \\
(-2.71)\end{array}$ & $\begin{array}{l}0.00607 \\
(1.43)\end{array}$ & $\begin{array}{l}-0.00371 \\
(-1.34)\end{array}$ & $\begin{array}{l}-0.00233 \\
(-0.73)\end{array}$ \\
\hline aid & & $\begin{array}{l}-0.302 * * * \\
(-3.35)\end{array}$ & $\begin{array}{l}-0.301 * * * \\
(-3.37)\end{array}$ & & $\begin{array}{l}-0.137 * \\
(-2.23)\end{array}$ & $\begin{array}{l}-0.161^{* *} \\
(-2.70)\end{array}$ \\
\hline rents & & $\begin{array}{l}0.271^{* *} \\
(3.15)\end{array}$ & $\begin{array}{l}0.270 * * \\
(3.13)\end{array}$ & & $\begin{array}{l}-0.199 * * \\
(-3.15)\end{array}$ & $\begin{array}{l}-0.184 * * * \\
(-3.67)\end{array}$ \\
\hline$f d i$ & & $\begin{array}{l}-0.226 * \\
(-1.87)\end{array}$ & $\begin{array}{l}-0.225 \\
(-1.81)\end{array}$ & & $\begin{array}{l}-0.391^{* * *} \\
(-8.20)\end{array}$ & $\begin{array}{l}-0.420 * * * \\
(-6.13)\end{array}$ \\
\hline polity & & $\begin{array}{l}0.127 \\
(0.40)\end{array}$ & $\begin{array}{l}0.125 \\
(0.39)\end{array}$ & & $\begin{array}{l}-0.579 * * \\
(-2.86)\end{array}$ & $\begin{array}{l}-0.545^{* *} \\
(-2.52)\end{array}$ \\
\hline$d c r$ & & $\begin{array}{l}-0.0942 * * * \\
(-5.38)\end{array}$ & $\begin{array}{l}-0.0942 * * * \\
(-5.42)\end{array}$ & & $\begin{array}{l}-0.0240 \\
(-1.16)\end{array}$ & $\begin{array}{l}-0.0246 \\
(-1.17)\end{array}$ \\
\hline $\inf$ & & $\begin{array}{l}0.00246 \\
(0.05)\end{array}$ & $\begin{array}{l}0.00306 \\
(0.06)\end{array}$ & & $\begin{array}{l}0.0187 \\
(0.31)\end{array}$ & $\begin{array}{l}0.00768 \\
(0.13)\end{array}$ \\
\hline scho & & $\begin{array}{l}0.0715^{*} \\
(2.08)\end{array}$ & $\begin{array}{l}0.0717^{*} \\
(2.04)\end{array}$ & & $\begin{array}{l}-0.0338 \\
(-0.60)\end{array}$ & $\begin{array}{l}-0.0377 \\
(-0.68)\end{array}$ \\
\hline remitinv & & & $\begin{array}{l}-0.000815 \\
(-0.12)\end{array}$ & & & $\begin{array}{l}0.0165 \\
(1.28)\end{array}$ \\
\hline Obs. & 250 & 201 & 201 & 232 & 192 & 192 \\
\hline R-sq (within) & 0.35 & 0.59 & 0.59 & 0.26 & 0.50 & 0.51 \\
\hline
\end{tabular}

The method of estimation is panel fixed effects OLS. The constant term is included (not reported). $t$ statistics shown in parenthesis are based on white robust standard errors which are clustered at the country level. Significantly different from zero at *90\%, **95\%, and *** 99\% confidence. We use one year lag of all RHS variables. 
Table 2: Panel fixed effects 2SLS regressions

\begin{tabular}{|c|c|c|c|c|}
\hline & $(2.1)$ & $(2.2)$ & $(2.3)$ & $(2.4)$ \\
\hline & $T b$ & $t b$ & nonoiltrade & nonoiltrade \\
\hline remit & $\begin{array}{l}-0.964 * * \\
(-2.50)\end{array}$ & & $\begin{array}{l}-1.338 * * * \\
(-3.29)\end{array}$ & \\
\hline remitpercapita & & $\begin{array}{l}-0.0575^{* * *} \\
(-3.06)\end{array}$ & & $\begin{array}{l}-0.0777 * * * \\
(-4.37)\end{array}$ \\
\hline inv & $\begin{array}{l}-0.729 * * * \\
(-3.76)\end{array}$ & $\begin{array}{l}-0.888 * * * \\
(-5.04)\end{array}$ & $\begin{array}{l}-1.016 * * * \\
(-5.00)\end{array}$ & $\begin{array}{l}-1.027 * * * \\
(-5.20)\end{array}$ \\
\hline remitinv & $\begin{array}{l}0.0124 \\
(0.83)\end{array}$ & & $\begin{array}{l}0.0263^{*} \\
(1.83)\end{array}$ & \\
\hline remitpcinv & & $\begin{array}{l}0.00143^{* *} \\
(2.54)\end{array}$ & & $\begin{array}{l}0.00132 \text { *** } \\
(2.71)\end{array}$ \\
\hline income1 & $\begin{array}{l}-0.116 \\
(-1.36)\end{array}$ & $\begin{array}{l}-0.126 \\
(-1.42)\end{array}$ & $\begin{array}{l}0.110 \\
(1.18)\end{array}$ & $\begin{array}{l}0.156^{*} \\
(1.73)\end{array}$ \\
\hline foreign income1 & $\begin{array}{l}-0.161 \\
(-1.40)\end{array}$ & $\begin{array}{l}-0.198 \\
(-1.43)\end{array}$ & $\begin{array}{l}-0.220^{* *} \\
(-2.05)\end{array}$ & $\begin{array}{l}-0.298 * * * \\
(-2.66)\end{array}$ \\
\hline exchange1 & $\begin{array}{l}-0.00417 \\
(-1.60)\end{array}$ & $\begin{array}{l}-0.00289 \\
(-1.03)\end{array}$ & $\begin{array}{l}0.00174 \\
(0.49)\end{array}$ & $\begin{array}{l}0.00188 \\
(0.53)\end{array}$ \\
\hline fdi1 & $\begin{array}{l}-0.211^{*} \\
(-1.68)\end{array}$ & $\begin{array}{l}-0.168 \\
(-1.19)\end{array}$ & $\begin{array}{l}-0.412^{* * *} \\
(-2.94)\end{array}$ & $\begin{array}{l}-0.0709 \\
(-0.58)\end{array}$ \\
\hline aid1 & $\begin{array}{l}-0.281^{* * *} \\
(-3.38)\end{array}$ & $\begin{array}{l}-0.318^{* * *} \\
(-3.60)\end{array}$ & $\begin{array}{l}-0.0902 \\
(-1.28)\end{array}$ & $\begin{array}{l}-0.0828 \\
(-1.30)\end{array}$ \\
\hline$d c r 1$ & $\begin{array}{l}-0.0737 * * \\
(-2.12)\end{array}$ & $\begin{array}{l}-0.0790 * * \\
(-2.20)\end{array}$ & $\begin{array}{l}0.0142 \\
(0.55)\end{array}$ & $\begin{array}{l}0.0329 \\
(1.17)\end{array}$ \\
\hline polity1 & $\begin{array}{l}0.412^{*} \\
(1.80)\end{array}$ & $\begin{array}{l}0.365 \\
(1.62)\end{array}$ & $\begin{array}{l}-0.201 \\
(-1.15)\end{array}$ & $\begin{array}{l}-0.319 * \\
(-1.76)\end{array}$ \\
\hline rents1 & $\begin{array}{l}0.363^{* * *} \\
(4.67)\end{array}$ & $\begin{array}{l}0.386^{* * *} \\
(4.94)\end{array}$ & $\begin{array}{l}-0.0992 \\
(-1.47)\end{array}$ & $\begin{array}{l}-0.0991 \\
(-1.43)\end{array}$ \\
\hline inf1 & $\begin{array}{l}0.0235 \\
(0.48)\end{array}$ & $\begin{array}{l}0.00659 \\
(0.14)\end{array}$ & $\begin{array}{l}0.0547 \\
(0.99)\end{array}$ & $\begin{array}{l}0.0652 \\
(1.19)\end{array}$ \\
\hline scho1 & $\begin{array}{l}0.0432 * \\
(1.66)\end{array}$ & $\begin{array}{l}0.0561^{* *} \\
(2.03)\end{array}$ & $\begin{array}{l}-0.0461 \\
(-1.41)\end{array}$ & $\begin{array}{l}0.00437 \\
(0.12)\end{array}$ \\
\hline Obs. & 194 & 194 & 185 & 185 \\
\hline R-squared & 0.62 & 0.62 & 0.56 & 0.60 \\
\hline $\begin{array}{l}\text { Underidentification test: } \\
\text { Kleibergen-Paap rk LM statistic (P- } \\
\text { value) }\end{array}$ & 0.000 & 0.000 & 0.000 & 0.000 \\
\hline $\begin{array}{l}\text { Weak identification test: } \\
\text { Kleibergen-Paap Wald rk F statistic }\end{array}$ & 11.628 & 14.052 & 28.333 & 25.310 \\
\hline $\begin{array}{l}\text { overidentification test of all } \\
\text { instruments: Hansen J statistic (P- } \\
\text { value) }\end{array}$ & 0.57 & 0.83 & 0.68 & 0.20 \\
\hline
\end{tabular}

The method of estimation is panel fixed effects 2SLS (xtivreg2). The constant term is included (not reported). $t$ Statistics shown in parenthesis are based on white robust standard errors which are clustered at the country level. Significantly different from zero at $* 90 \%$, $* * 95 \%$, and $* * * 99 \%$ confidence. Instrumented variables are remit, inv, and remitinv. Excluded instruments are two years lags of instrumented variables. One-year lag of other control variables are assumed to be pre-determined. The critical values for the Kleibergen-Paap rk Wald F statistic are in Stock and Yogo (2005): 12.20 for 5\% maximal IV relative bias; 7.77 for 10\% maximal IV relative bias; 5.35 for 20\% maximal IV relative bias; and 4.40 for $30 \%$ maximal IV relative bias. Kleibergen-Paap rank LM-statistic (Baum, et al. 2007; Kleibergen and Paap 2005): The test statistic strongly rejects the null hypothesis of underidenfication. Kleibergen-Paap rank Wald F-statistic (Baum, et al. 2007; Kleibergen and Paap 2005): The test statistic rejects the null hypothesis of weak identification. Hansen J-statistics (Baum, et al. 2007): The test statistics do not reject the null hypothesis of zero correlation between the instrumental variables and the error term. 


\section{References}

Adams, H. (1991). The economic uses and impact of international remittances in rural Egypt. Economic Development and Cultural Change, 39(4): 695-722.

Adams, R., and Page, J. (2005). Do international migration and remittances reduce poverty in developing countries?. World Development, 33(10): 1645-1669

Amuedo-Dorantes, C., and Pozo, S. (2011). Remittances and income smoothing. American Economic Review, 101(3): 582-87

Amuedo-Dorantes, C., and Pozo, S. (2004). On the use of differing money transmission methods by mexican immigrants. Economic Working Papers at Centro de Estudios Andaluces E2004/06.

Anwar, S., and Cooray, A. (2015). Financial flows and per capita income in developing countries. International Review of Economics \& Finance, 35: 304-314

Bahmani-Oskooee, M., and Ratha, A. (2004). The J-curve: a literature review. Applied Economics, 36: 1377-98.

Baltagi, B. (2008). Econometric analysis of panel data (4 ${ }^{\text {th }}$ ed.). Wiley: UK.

Baum, C., Schaffer, M., and Stillman, S. (2007). Enhanced routines for instrumental variables/generalized method of moments estimation and testing. Stata Journal, 7(4): 465506.

Barro, R., and Sala-i-Martin, X. (2004). Economic growth. $2^{\text {nd }}$ edition. Cambridge, MA: MIT Press.

Bhatta, G. (2013). Remittance and trade deficit nexus in Nepal: A VECM approach. NRB Economic Review, Nepal Rastra Bank, Research Department, 25(1): 37-50.

Bhattacharyya, S., and Hodler, R. (2010). Natural resources, democracy and corruption. European Economic Review, 54(4): 608-621. 
Biswas, A., Farzanegan, M.R., and Thum, M. (2012). Pollution, shadow economy and corruption: theory and evidence. Ecological Economics, 75: 114-125.

Bjorvatn, K., and Farzanegan, M.R. (2015). Resource rents, balance of power, and political stability. Journal of Peace Research, 52(6): 758-773.

Bjorvatn, K., and Farzanegan, M.R. (2013). Demographic transition in resource rich countries: a blessing or a curse?. World Development, 45, 337-351.

Bjorvatn, K., Farzanegan, M.R., and Schneider, F. (2012). Resource curse and power balance: evidence from oil rich countries. World Development, 40(7): 1308-1316.

Brown, R., Carmignani, F, and Fayad, G. (2014). Migrants' remittances and financial development: macro- and micro-level evidence of a perverse relationship. The World Economy, 36(5): 636-660.

Bouhga-Hagbe, J. (2004). A theory of workers' remittances with an application to Morocco. IMF Working Paper No. 04/194.

Catrinescu, N., Leon-Ledesma, M., Piracha, M., and Quillin, B. (2009). Remittances, institutions, and economic growth. World Development, 37(1): 81-92.

CBO (2000). Causes and consequences of the trade deficit: an overview. Congressional Budget Office: Washington.

Chaudhary, M., and Qaisrani, A. (2002). Trade Instability, Investment and Economic Growth in Pakistan. Pakistan Economic and Social Review, XL(1): 57-73.

De Silva, S., and Juregui, C. (2004). Migration and trade and in MENA: problems or solutions?. World Bank Working Paper Series No. 40:1-40.

Drinkwater, S., Levine, P., and Lotti, E. (2003). The labor market effects of remittances. University of Surrey, school of economics discussion paper No. 1906.

EIB, (2006). Study on improving the efficiency of workers' remittances in Mediterranean 
countries. European Investment Bank, Rotterdam, The Netherlands. Retrieved from http://www.eib.org/attachments/country/femip_workers_remittances_en.pdf

El Sakka, M., and McNabb, R. (1999). The macroeconomic determinants of emigrant remittances. World Development, 27(8): 1493-1502.

El Wassal, K. (2012). The impact of trade liberalization on trade balance in Arab countries. Journal of Economic and Social Research, 14(2): 1-26.

Elwel, C. (2007). The U.S. trade deficit: causes, consequences, and cures. Congressional Research Service (CRS) report no RL31032.

Farzanegan, M.R. (2014). Can oil-rich countries encourage entrepreneurship?. Entrepreneurship \& Regional Development: An International Journal, 26(9-10): 706-725.

Giuliano, P., and Ruiz-Arranz, M. (2009). Remittances, financial development and growth. Journal of Development Economics, 90(1): 144-152.

Glytsos, N. (1993). Measuring the income effects of migrant remittances: a methodological approach applied to Greece. Economic Development and Cultural Change, 42(1): 131168.

Goldstein, M., and Khan, M. (1985). Income and price effects in foreign trade. Handbook of International Economics, 2: 1041-1105.

Gopalan, S. and Rajan, R. (2010). External financing in South Asia: the remittances Option. United Nations Economic and Social Commission for Asia and the Pacific (ESCAP), $\begin{array}{lllll}\text { Policy brief } & \text { No. } & 23 . & \text { Retrieved }\end{array}$ http://www.unescap.org/sites/default/files/polbrief23.pdf

Hadad, M. (2000). Export competitiveness: where does the Middle East and North Africa region stand?. Economic Research Forum (ERF), Working paper No. 2030.

Imai, K., Gaiha, R., Ali, A., and Kaicker, N. (2014). Remittances, growth and poverty: new evidence from Asian countries. Journal of Policy Modelling, 36(3): 524-538 
IOM (2010). A study on remittances and investment opportunities for Egyptian migrants. International Organization for Migration (IOM), Cairo, Egypt.

Jahjah, S, Chami, R., and Fullenkamp, C. (2003). Are immigrant remittance flows a source of capital for development? IMF Staff Papers, 52(1); 55-81.

Kandil, M., and Mirzaie, I. (2008). The impact of capital and remittance flows on economic performance in MENA countries. World Economics, 10(3): 159-192.

Kleibergen, F., and Paap, R. (2006). Generalized reduced rank tests using the singular value decomposition. Journal of Econometrics 133(1): 97-126.

Koska, O., Saygin, P., Çağatay, S, and Artal-Tur, A. (2013). International migration, remittances, and the human capital formation of Egyptian children. International Review of Economics \& Finance, Special Issue: The Dynamics of International Migration, 28: $38-50$

Loser, C., Lockwood, C., Minson, A., and Balcazar, L. (2006). The macroeconomic impact of remittances in Latin America: Dutch Disease or Latin Cure?. Inter-American Dialogue, Washington DC. Retrieved from https://www.monroecollege.edu/uploadedFiles/_Site_Assets/PDF/Remittances-in-LatinAmerica.pdf.

Makdisi, S., et al. (2007). Determinants of growth in the MENA countries. In Nugent J. and Pesaran H. (Eds.), explaining growth in the Middle East, pp.31-60. Elsevier: London.

Marshall, M., Jaggers, K., and Gurr, T. (2011). Polity IV project: political regime characteristics and transitions, 1800-2010. Dataset users’ manual. Center for Systemic Peace, Vienna.

Mim, S. and Ben Ali, M (2012). Through which channels can remittances spur economic growth in MENA countries?. The Open-Access, Open-Assessment E-Journal, 6(33): 1—27.

Nabli, M., (2007). Long-term economic development challenges and prospects for the Arab countries. In Nabli M. (Eds.), breaking the barriers to higher economic growth: better 
governance and deeper reforms in the Middle East and North Africa, pp.1-28. The World Bank: Washington.

OECD (2006). International Migration Outlook. International Migrant Remittances and Their Role of Development. Organization for Economic Cooperation and Development (OECD): Paris.

Okodua, H. and Olayiwola, W. (2013). Migrant workers' remittances and external trade balance in Sub-Sahara African countries. International Journal of Economics and Finance; 5(3): 134-142.

Page, J. and Van Gelder, L. (2001). Missing links: institutional capability, policy reform and growth in the Middle East and North Africa. In Hakimian H. and Moshaver Z.(Eds.), the state and global change: the political economy of transition in the Middle East and North Africa, pp. 15-58. Curzon Press: London.

Pfaffermayr, M. (1996) Foreign outward direct investment and exports in Austrian manufacturing: substitutes or complements?. Weltwirtschaftliches Archive 132(2): 501522.

Ramirez, M. and Sharma, H. (2008). Remittances and growth in Latin America: a panel unit root and panel cointegration analysis. Estudios Economicos de Desarrollo Internacional, Euro-American Association of Economic Development, 9(1): 5-36.

Roodman, D. (2006). How to do xtabond2: an introduction to "Difference” and "System” GMM in Stata. The Stata journal, 9(1); 86-136.

Rose, A., and Yellen, J. (1989). Is there a J-curve? Journal of Monetary economics, 24(1): 5368.

Schramm, C. (2009). Migration from Egypt, Morocco and Tunisia: synthesis of three case studies. Background paper for Shaping the Future, The World Bank, Washington DC.

Shakur, S. (2012). Impact of global trade liberalization on regional trade balances. International 
Journal of Economics and Finance, 4(1): 48-55.

Straubhaar, T. (1991). On the economics of international labor migration. Gunter Steinmann Weltwirtschaftliches Archive, Springer, Stuttgart.

Stock, J., and Yogo, M. (2005). Testing for weak instruments in linear IV regression. In Andrews D. and Stock J. (Eds.), identification and inference for econometric models: essays in honor of Thomas, pp. 80-108. Cambridge University Press: New York.

Stučka, T. (2004). The effects of exchange rate change on the trade balance in Croatia. IMF working paper WP/04/65.

Taylor, J., Arango, J., Hugo, G, Kouaouci, A., Massey, D., and Pellegrino, A. (1996). International migration and national development. Population Index, 62(2): pp. 181-212.

Thirlwall, P. (1999). Growth and Development. Macmillan, $6^{\text {th }}$ Edition. England.

Verbeek, M. (2004). A guide to modern econometrics. John Wiley \& Sons Ltd, $2^{\text {nd }}$ edition, England.

World Bank (2016). World Development indicators. The World Bank: Washington.

World Bank, (2009). From Privilege to Competition Unlocking Private-Led Growth in the Middle East and North Africa. MENA development report. The World Bank: Washington.

World Bank, (2007). Middle East and North Africa region: 2007 economic developments and prospects. job creation in an era of high growth. The World Bank: Washington.

World Bank, (2006). Global economic prospects: the economic implications of remittances and migration. The World Bank: Washington.

World Bank, (2003). Trade, investment and development in the Middle East and North Africa: engaging with the world. The World Bank: Washington. 
World Bank. Migration and development brief, various issues. The World Bank: Washington.

World Economic Outlook, (2015). IMF database. IMF: Washington.

WTO, (2013). World Trade report. World Trade Organization (WTO): Geneva. 


\section{Appendix A}

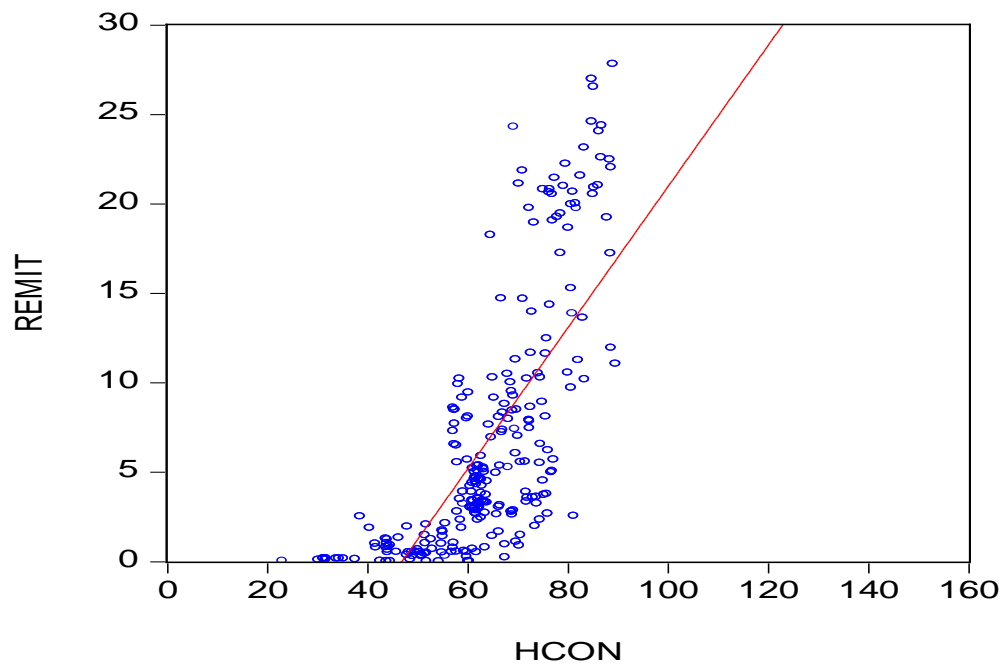

Figure A1: Panel regression line between household consumption expenditures and remittances. LA countries (1980-2012) Source: World Bank, (2016) and author's calculations

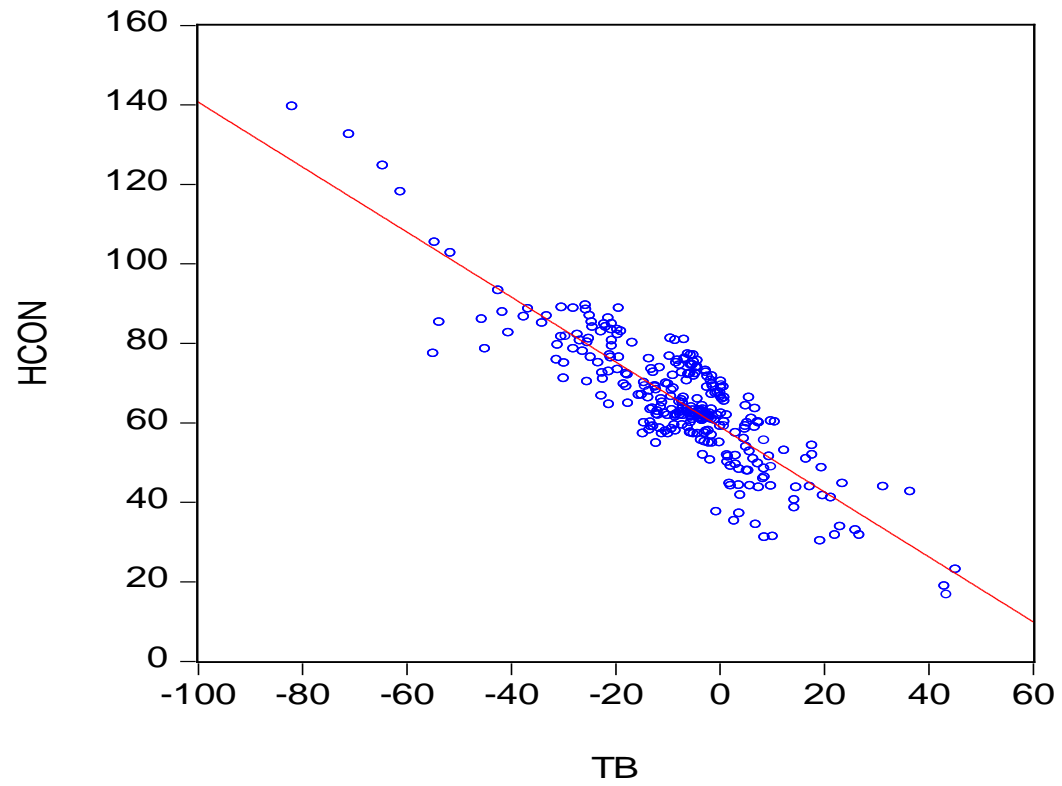

Figure A2: Panel regression line between household final consumption expenditures and trade balance. LA countries (1980-2013)

Source: World Bank, (2016) and author's calculations 
Table A1: Usage of remittances in selected LA MENA countries (Percentage of remittances)

\begin{tabular}{lcccccc}
\hline \hline & Daily expenses & $\begin{array}{c}\text { Payment of } \\
\text { school fees }\end{array}$ & $\begin{array}{c}\text { Building a } \\
\text { house }\end{array}$ & Investments & Other & $\begin{array}{c}\text { Number of } \\
\text { interviews }\end{array}$ \\
\hline Algeria & 45 & 13 & 23 & 5 & 11 & 64 \\
Egypt & 43 & 12 & 18 & 15 & 12 & 31 \\
Jordan & 74 & 16 & 4 & 6 & - & 40 \\
Lebanon & 56 & 24 & 5 & 5 & 5 & 41 \\
Morocco & 46 & 31 & 16 & 5 & 2 & 40 \\
Syria & 61 & 11 & 8 & - & 20 & 49 \\
\hline \hline
\end{tabular}

Source: EIB, (2006)

Table A2. Descriptive statistics of key variables

\begin{tabular}{lcccc}
\hline \hline Variable & Mean & $\begin{array}{c}\text { Standard } \\
\text { deviation }\end{array}$ & Maximum & Minimum \\
\hline$t b$ & -6.627 & 14.00 & 45.259 & -54.897 \\
remit & 6.787 & 6.986 & 27.814 & 0.005 \\
inv & 25.927 & 6.852 & 46.876 & 9.341 \\
income & 2.045 & 10.78 & 102.77 & -65.02 \\
foreign income & 3.065 & 3.445 & 15.207 & -6.370 \\
exchange & 179.29 & 178.429 & 1177.21 & 51.380 \\
\hline \hline
\end{tabular}


Table A3: Variables' definitions and sources

\begin{tabular}{|c|c|c|}
\hline Variable & Definition & Source \\
\hline$d c r$ & $\begin{array}{l}\text { Domestic credit to private sector as a proxy for financial sector } \\
\text { development refers to financial resources provided to the private sector } \\
\text { by financial corporations (as a share of GDP). }\end{array}$ & World Bank, (2016) \\
\hline$t b$ & $\begin{array}{l}\text { Trade balance comprise of exports of goods and services minus imports } \\
\text { of goods and services (as a share of GDP). }\end{array}$ & World Bank, (2016) \\
\hline polity & $\begin{array}{l}\text { Polity } 2 \text { is a modified version of the annual polity index which examines } \\
\text { qualities of democratic and autocratic authority in governing institutions. } \\
\text { The Polity scores are interpreted as follows, "autocracies" }-10 \text { to }-6 \text {, } \\
\text { "anocracies" }-5 \text { to }+5 \text { and three special values: - } 66 \text { (foreign } \\
\text { interruptions), }-77 \text { (interregnum) and -88 (transitional cases), and } \\
\text { "democracies" + } 6 \text { to }+10 \text {. }\end{array}$ & Marshall et al., (2011) \\
\hline remit & $\begin{array}{l}\text { Personal remittances comprise personal transfers and compensation of } \\
\text { employees (as a share of GDP). }\end{array}$ & World Bank, (2016) \\
\hline inv & $\begin{array}{l}\text { Gross fixed capital formation (formerly gross domestic fixed investment) } \\
\text { includes land improvements (fences, ditches, drains, and so on); plant, } \\
\text { machinery, and equipment purchases, etc. }\end{array}$ & World Bank, (2016) \\
\hline $\inf$ & Inflation rate (GDP deflator index). & World Bank, (2016) \\
\hline fdi & Net Inflows of foreign direct investments (as a share of GDP). & World Bank, (2016) \\
\hline exchange & $\begin{array}{l}\text { Real effective exchange rate is the nominal measure of the value of a } \\
\text { currency against a weighted average of several foreign currencies) } \\
\text { divided by a price deflator } 2010 \text { (measured in a way that its increase } \\
\text { implies appreciation of domestic currency). }\end{array}$ & Bruegel dataset \\
\hline aid & $\begin{array}{l}\text { Net official development assistance (ODA) as a share of GDP consists of } \\
\text { disbursements of loans made on concessional terms (net of repayments } \\
\text { of principal) and grants by official agencies of the members of the } \\
\text { Development Assistance Committee (DAC) and by non-DAC countries. }\end{array}$ & World Bank, (2016) \\
\hline rents & $\begin{array}{l}\text { Total natural resources rents are the sum of oil and other natural } \\
\text { resources rents (as a share of GDP). }\end{array}$ & World Bank, (2016) \\
\hline income & Annual growth of real GDP per capita. & World Bank, (2016) \\
\hline foreign income & $\begin{array}{l}\text { Weighted average of annual real GDP growth of the } 5 \text { main trading } \\
\text { partners for each country. }\end{array}$ & World Bank, (2016) \\
\hline scho & $\begin{array}{l}\text { Gross enrolment ratio measure total enrolment that officially corresponds } \\
\text { to the level of education shown. }\end{array}$ & World Bank, (2016) \\
\hline
\end{tabular}

